\title{
THE APPLICATION OF SIMPLE ACCOUNTING FORMAT IN TRADISIONAL SHOP
}

\author{
Dedeh $^{1)}$, Dendy Syaiful Akbar ${ }^{2)}$, Rizka Andhika Putra ${ }^{3)}$ \\ ${ }^{1,3}$ Program Studi Pendidikan Akuntansi \\ Fakultas Ilmu Pendidikan dan Keguruan Universitas Galuh Ciamis \\ Email: dedeh.akt15@gmail.com; rizkaandhikaputra@gmail.com \\ ${ }^{2}$ Program Studi Akuntansi \\ Fakultas Ekonomi Universitas Galuh Ciamis \\ Email: dendysyaifu11984@gmail.com
}

Diterima: September 2019; Direvisi: 29 Oktober 2019; dipublikasikan: 11 Desember 2019

\begin{abstract}
This study offers to determine the ability of 20 types of MSMEs to trade in the environment around the Universitas Galuh Ciamis campus. The research method used was an experimental method, in which we applied a simple accounting format to their business. The analysis technique used is a different test (t-test) through scores obtained from test results to them before and subsequently applied to a simple accounting format. The results obtained show their low skills in preparing financial statements, as evidenced by the tests before applying a simple accounting format obtained an average score of 27.80. After applying the accounting format, improvements are made to those who prepare financial statements using a simple accounting format. From the test results applied a simple accounting format, obtained an average score of 71.20. So it can be concluded from the changes that occur before and after applying a simple accounting format for MSMEs in the type of business in the environment around the Universitas Galuh Ciamis campus.
\end{abstract}

Keywords: Accounting, MSMEs, SAK.

\begin{abstract}
ABSTRAK
Penelitian ini bertujuan untuk mengetahui kemampuan 20 pelaku UMKM jenis usaha dagang di lingkungan sekitar kampus Universitas Galuh Ciamis. Metode penelitian yang digunakan adalah metode eksperimen, dimana kami melakukan penerapan format akuntansi sederhana pada usaha mereka. Teknik analisis yang digunakan adalah uji beda ( $t$-test) melalui skor yang diperoleh dari hasil tes kepada mereka sebelum dan sesudah diterapkannya format akuntansi sederhana. Hasil yang diperoleha menunjukan rendahnya keterampilan mereka dalam menyusun laporan keuangan usahanya, terbukti dari tes sebelum diterapkan format akuntansi sederhana diperoleh skor rata-rata 27,80. Setelah diterapkan format akuntansi sederhana terjadi peningkatan keterampilan mereka dalam menyusun laporan keuangan menggunakan format akuntansi sederhana. Terukti dari hasil tes sesudah diterapkan format akuntansi sederhana, diperoleh skor rata-rata 71,20. Maka dapat disimpukan bahwa terjadi perubahan keterampilan sebelum dan sesudah diterapkan format akuntansi sederhana pada UMKM jenis usaha dagang di lingkungan sekitar kampus Universitas Galuh Ciamis.
\end{abstract}

Kata Kunci: Akuntansi, UMKM, SAK. 


\section{INTRODUCTION}

MSMEs activities in Indonesia are expected to be a pillar in an effort to increase economic growth in Indonesia. MSMEs have a contribution in opening employment opportunities and increasing state income, especially in the non-oil sector. The increasing role in the creative economy based on MSMEs requires forms of innovation, both physical and nonphysical (Nurranto, Kurniadi\&Gayatri, 2019). Based on the Republik of Indonesia Law No. 20 of 2008 concerning MSMEs, small and medium enterprises are independent economic productive businesses carried out by individuals or business entities that are not subsidiaries or branch companies that are owned, controlled or incorporated, either directly or indirectly with small businesses or results annual sales as stipulated in law.

According to the Law of the Republic of Indonesia, No 20 of 2008 concerning MSMEs referred to as MSMEs is an entity that has Criteria: 1) Net assets owned by micro-businesses, namely IDR50,000,000 in this case, not including building and land assets. As for the annual sales results of IDR300,000,000; 2) Net assets owned by small businesses, namely IDR50,000,000 to Rp500,000,000, in this case not including building and land assets. As for the annual sales results of IDR2,500,000,000.00; 3) Net assets owned by medium-sized businesses, namely IDR500,000,000 to IDR10,000,000,000 in this case not including building and land assets. As for the annual sales results of IDR2,500,000,000 up to IDR50,000,000,000.

The State Ministry of Cooperatives and Small and Medium Enterprises said that efforts to empower MSMEs from year to year are always monitored and evaluated for developments, both in terms of their contribution to the creation of GDP, employment, exports and the development of business actors as well as the existence of small and medium business investment through gross fixed capital formation. The overall macroeconomic indicators are always used as a reference in the preparation of MSMEs empowerment policies and an indicator of the success of implementing the policies that have been implemented in the previous year.

The development of MSMEs that are engaged in trade types has great potential if this can be managed and developed properly will certainly be able to realize a resilient medium business. Meanwhile, on the other hand MSMEs in the type of trading business are also still faced with problems that lie in the administrative process. The government has tried to help overcome the obstacles faced by most small and medium-sized commercial businesses, such as conducting coaching and extending credit. But a new problem arose, MSMEs in the type of trading business were required to include financial statements as a condition for applying for loans to banks. Because the banks themselves do not want to take risks in lending to MSMEs because banks do not know the development of the business (Ernawati, Asyikin, \& Sari, 2016).

From these conditions, it is evident that accounting is very important for the sustainability of MSMEs. Accounting is one of the important indicators in the business world, including in the MSMEs sector. Accounting is the process of preparing and presenting financial statements, where the information contained in the financial statements is useful for the company's strategic decision making related to business financial management. Saragih\&Surikayanti (2015) argues that the information allows MSMEs to identify and predict problem areas that may arise, then take corrective actions in a timely manner. Meanwhile,Astuti (2010) expressed the opinion that one of the benefits, if MSMEs compile financial reports, is to be one of the ingredients in decision making.

In fact, MSMEs in Indonesia currently operate without relying on financial information that is prepared systematically and structured. Such a condition causes the information generated from the financial statements to be inadequate and not in accordance with the actual situation (Akbar \&Dedeh, 2017; Badria\& Diana, 2018). Most MSMEs in Indonesia still think that preparing financial reports is a luxury and there is no benefit, so MSMEs do not know 
exactly how much income is received, what operating costs are incurred and how much is left (Savitri\&Saifudin , 2018; Akbar \&Dedeh, 2017; Salmiah, Nanda, \&Adino, 2018).

Based on the results of an initial survey of MSMEs, the types of trading businesses around the UniversitasGaluhCiamis campus also do not have systematic financial accounting. They only did a makeshift financial record using ordinary notebooks. The notebook only contains notes on the list of accounts receivable only. The impact is traders can not know the number of profits obtained each period. Other problems they do not apply one of the accounting principles, namely the principle of the entity. The principle of entity requires the separation of business finances from the personal finances of the owner. Their conditions do not separate business finance from personal finance, so business development cannot be known with certainty.

Currently, there are accounting standards that are suitable for small businesses, namely the StandarAkuntansikeuangan (SAK) EntitasMikro, Kecil danMenengah (EMKM). SAK EMKM is structured to be able to encourage and facilitate MSME financial reporting needs. Many studies have proven that some MSMEs have not implemented the StandarAkuntansiKeuanganEntitasTanpaAkuntabilitasPublik (SAK ETAP) appropriately, because the SAK is still considered too complex and not in accordance with the needs of MSMEs actors, the research recommends the preparation of simpler financial statements (Akbar et al., 2019). So that the IkatanAkuntan Indonesia (IAI) issued SAK EMKM which is expected that its reporting framework can assist entities in making the transition from cash-based reporting to accrual-basis reporting (IAI, 2016 in Badria\& Diana, 2018).

Financial management at MSMEs in Indonesia is still alarming, as evidenced by several research results showing that MSMEs actors still do not consider it necessary to prepare their business financial statements. The results of research conducted by Saragih\&Surikayanti (2015) show that the financial statements prepared by MSMEs in Medan Perjuangan are only limited to income statements, and even then they are incomplete. Meanwhile, research conducted by Wilujeng (2013) shows that MSMEs in Surabaya do not yet have adequate financial reports and are not aware of any relevant accounting standards applied to MSMEs. In line with the results of the study, research conducted by Azaria (2013) shows that the financial statements made by MSMEs in Unggulandi in Blitar Regency are still very simple with incomplete financial information.

Based on the results of some of the previous studies, the writer will develop the previous research by experimenting with the application of a simple accounting format to the MSMEs of the types of trading businesses around the UniversitasGaluhCiamis campus. The simple accounting format that was made previously refers to the relevant accounting standards applied to the MSMEs (SAK EMKM) type of trading business. The contribution in this research lies in the application of a simple accounting format that has been made by researchers and then will be tested for changes in knowledge and skills that occur in these small traders before and after the application of a simple accounting format.

\section{METHOD}

The research method used in this study is an experimental method, wherein this study is to apply a simple accounting format for 20 MSMEs of types of trading businesses around the campus of UniversitasGaluhCiamis. The type of data collected is primary data and secondary data. Primary data obtained from the source directly with interview techniques to determine the conditions before and after the application of a simple accounting format. While secondary data were collected by observation techniques to determine the condition of the financial accounting of businesses before and after applying a simple accounting format. Meanwhile, the simple 
accounting format that will be applied is an accounting format that has been previously designed by applying accounting standards for MSMEs and adjusted to the character of the type of trading business.

Data analysis techniques in this study used a different test (t-test) to determine the changes that occurred before and after applying a simple accounting format in the MSMEs in question. To support this different test, it is carried out by providing a test of understanding and skills carried out before and after the application of simple accounting. The test material provided is the practice of applying a simple accounting format.

\section{RESULT AND DISCUSSION}

The first step in this research was to dial the test before the application of a simple accounting format to 20 MSMEs of trading businesses around the UniversitasGaluhCiamis campus. The test material given is the skill in applying a simple accounting format. Table 1 shows a description of the overall test results before applying a simple accounting format:

Table 1 Descriptive Statistics of Test_1 Result

\begin{tabular}{|c|c|c|c|c|c|}
\hline & & Minimum & Maximum & Mean & Std. Deviation \\
\hline Test_1 & 20 & 10.00 & 41.00 & 27.8000 & 9.31665 \\
\hline Valid N (listwise) & 20 & & & & \\
\hline
\end{tabular}

Source: Data Processing Using SPSS

In the table, it can be seen the score generated on the first test, with a minimum score of 10.00 , a maximum score of 41.00 , and an average score of 27.80 . The acquisition score shows that the skills in preparing financial statements in accordance with the accounting principles of 20 MSMEs types of trading businesses around the UniversitasGaluhCiamis campus are still low. Based on the information obtained from them, the low skill in preparing financial statements is due to the low educational background, as well as their low knowledge of the importance of accounting in the business world.

In general, the types of MSMEs in the business environment around the campus of UniversitasGaluhCiamis have not been able to make business performance reports and financial reports in accordance with generally accepted accounting standards. This happens because they are not accustomed to recording and compiling financial statements as a description of business activities and financial position of the company. Most of them only record the amount of money received and the amount of money spent, the number of goods bought and sold, and the number of receivables or debts. But the recording is only a reminder and not the format desired by the banks as a condition for credit applications.

The impact of unstructured and systematic bookkeeping in accordance with accounting rules is that the net profit or loss of operating results cannot be known. In addition, with traditional bookkeeping, it is difficult for them to access capital from banks, because one of the conditions for applying for credit is the existence of good bookkeeping for the banking analysis process. In addition, access to capital assistance from the government is also required for good business financial accounting, with the aim that the business is sustainable.

The second stage is to implement a simple accounting format for 20 MSMEs of business types in the campus environment of UniversitasGaluhCiamis. At this stage, training is carried out in one of the classrooms in the Accounting Education Study Program at UniversitasGaluhCiamis. Participants were given the training to prepare financial reports using a simple accounting format. During the training, the participants were very enthusiastic, as evidenced by their communicative activities. After being given training, direct implementation 
of a simple accounting format is carried out in their businesses. A simple accounting format is extended for their daily use in running their business. The accounting format provided is the printed version because their ability to operate computers is still low. Following are the simple accounting format materials that are applied:

1. Cash Book

This cash book is made to record income and expenditure transactions for cash. Cash income comes from cash sales of merchandise transactions, in addition to cash income comes from creditors' payments related to credit sales transactions. Spending on cash occurs from purchases of merchandise in cash for inventory needs, in addition to spending on cash also occurs when companies make expenditures on cash related to expenses or costs that are borne by the company.

2. Inventory Book

This inventory book is used to record the entry of merchandise. Exit merchandise occurs when a company sells its merchandise or there is merchandise that is not feasible to sell to consumers or transaction returns, thereby reducing the amount of inventory. The entry of merchandise occurs when the company buys merchandise, thereby increasing the amount of inventory. The main purpose of this inventory book is made so that the stall owner can find out the amount of inventory at any time so that the stall owner can know the cost of goods sold as well as the cost of goods inventory ready to sell. This inventory book is equipped with the name of the goods so that the stall owner can control each type of merchandise.

3. Debt Book

This debt book is used to record liabilities or business debts caused by the purchase of merchandise on credit or capital loans to debtors. With the existence of this debt book, shop owners can find out their debt balance at any time. The debt book is equipped with the name of the debtor, so this debt book will be more informative.

4. Receivable Book

This accounts receivable book is used to record the balance of receivables owned by the company. These receivables arise from the sale of merchandise on credit from consumers. The book of accounts receivable is equipped with the name of the creditor so that the shop owner can find out the balance of accounts receivable per customer.

5. Supplies Book

This equipment book is used to record equipment balances. Equipment in the traditional warung business is in the form of stationery such as books, pencils, pens, highlighter, paper, books, and other supplies. This equipment book is made with the aim that the shop owner can find out the number of supplies at any time. Equipment that has been used will be used as operating expenses every period and reported in the income statement as an equipment expense.

6. Fixed Asset Book

The book of fixed assets is used to record the depreciation of fixed assets owned by the company. Fixed assets that are depreciated in traditional stalls can be in the form of vehicles, equipment (cabinets, chairs, tables, storefronts, etc.), buildings and other fixed assets. The sheet in the book of fixed assets can be used for a period of one year because the recording of depreciation of fixed assets is done at the end of each month and will be reported as a depreciation expense in the income statement.

7. Financial Statement

Financial reports are made per month with the aim that the stall owner can find out the development of the business he is running. The financial statements consist of 3 types of reports which include the income statement, the report on capital changes and also the statement of financial position. The following is an explanation of each financial statement:

a) Income Statement 
This income statement is made to determine whether in the period concerned the company made a profit or loss. To find the profit or loss of the results of operations, the owner of the company can do this by pairing total net sales (after deducting the cost of sales) with costs. If the total net sales are greater than the total costs, the company gets a profit, whereas if the total net sales are smaller than the total costs, then the company gets a loss.

b) Changes in Capital Statement

This capital change report is made to be able to know the changes in the capital that occur at the end of the period (per month) due to profit or loss generated during one accounting period, as well as the existence of cash withdrawals that are carried out by the business owner for his personal needs. This capital change is known by adding the initial capital of the period with the profit generated at the end of the period minus the take-up of cash by the owner, then the result is the end-of-period capital. The end period capital is used as initial capital in the next period. If the company suffers a loss at the end of the period, then the initial capital of the period is reduced by losses and withdrawal of cash by the owner, then the result is the end of period capital.

c) Position of Financial Statement

This financial position statement is made to determine the financial position which consists of assets, liabilities or debt and capital. This report is made by recording the types of assets and their balance in the left column after deducting the depreciation of the fixed assets value, while the right column records the types of debt and their balance and records the end of period capital and the balance. The right-hand column shows the total assets in the left-hand column. Because the company's assets are total debt plus capital.

The third stage was to carry out a test after being given training and the application of a simple accounting format to 20 MSMEs types of trading businesses in UniversitasGaluhCiamis. Table 2 shows a description of the overall test results before applying a simple accounting format:

Table 2 Descriptive Statistics of Test_2 Result

\begin{tabular}{llrrrr}
\hline & N & Minimum & Maximum & Mean & Std. Deviation \\
\hline Test_2 & 20 & 55.00 & 90.00 & 71.2000 & 10.10784 \\
\hline Valid N (listwise) & 20 & & & & \\
\hline Source: Data Processing Using SPSS & & &
\end{tabular}

In the table, it can be seen the score generated on the second test, with a minimum score of 55.00, a maximum score of 90.00, and an average score of 71.20. The acquisition score shows that the skills in preparing financial statements in accordance with the accounting principles of 20 MSMEs types of trading businesses around the campus of UniversitasGaluhCiamis have increased. To measure how changes occur before and after the adoption of a simple accounting format, a different t-test is performed. Table 3 provides information about these changes.

Table 3 One-Sample Statistics

\begin{tabular}{lllrr}
\hline & N & Mean & Std. Deviation & Sig \\
\hline Test_1 & 20 & 27.8000 & 9.31665 & .000 \\
\hline Test_2 & 20 & 71.2000 & 10.10784 & .000 \\
\hline
\end{tabular}

Source: Data Processing Using SPSS 
The table shows that there is a significant change in skills of the 20 MSMEs of types of trading businesses in UniversitasGaluhCiamis before and after the training and application of a simple accounting format to their businesses. Simply change can be seen from the average score achieved from Test_1 is 27.80 and Test_2 71.20 with a significance level of 0,000 or below the required level of significance, which is 0.05 . These results indicate an increase in the skills of preparing financial statements using a simple accounting format from the MSMEs of the type of trading business in UniversitasGaluhCiamis.

Surely there are many benefits to be obtained if MSMEs continues to compile financial reports in accordance with accounting rules. These benefits include 1) being able to find out information about the financial position, financial performance, and changes in owner's capital; 2) can be used as a basis for strategic decision making; 3) can know the value of changes in cash inflows and outflows. Based on the cash flow statement, MSMEs will find out how much the increase or decrease in cash in each period. In addition, MSMEs actors can obtain information from where the cash sources come from, where the allocations will be issued and what amount of cash receipts and disbursements, both from operations, investments and from funding.

Therefore, financial records are very important for all types of businesses, especially to avoid things that can harm the company. Many novice business people often ignore the financial records of their businesses, due to a lack of understanding of the importance of accounting in the business world. As the MSMEs business advances and requires additional capital, the financial statements of the business will be seen by the banking sector. Therefore, MSMEs must neatly conduct financial records periodically from the start.

A serious problem faced by MSMEs at present is trade liberalization, such as the entry into force of the ASEAN-China Free Trade Area (ACFTA) which was effective in 2010 and agreed upon by the Government of Indonesia in the form of an agreement. Pawitan (2012) in his research explained that the presence of ACFTA at that time until now threatened the existence of local products, including products produced by MSMEs in Indonesia. This condition is even tougher for MSMEs in Indonesia with the implementation of the ASEAN Economic Community (AEC) in 2015. In the era of free trade, the Government of Indonesia did not consider the readiness of MSMEs to compete, such as the readiness of product quality, market readiness and the readiness of its human resources in managing businesses, including financial management (Akbar et al., 2019). Phijaisanit (2017) said that in the era of free trade entrepreneurs in ASEAN must be able to compete by efficiently mobilizing their resources.

Actually, the rapid development of MSMEs has made a real contribution in providing employment and income for the people of Indonesia. Therefore, empowerment and sustainable development need to be done so that MSMEs not only grow in numbers but also develop in the quality of the competitiveness of their products. The empowerment of the MSMEs sector has become very strategic, because of its great potential in driving the community's economy and at the same time becoming the source of income for the majority of the community in improving their welfare. The importance of MSMEs in developing countries can overcome various economic and social problems such as reducing unemployment, eradicating poverty and equitable distribution of income. For this reason, various studies to provide solutions for the development of MSMEs must continue to be carried out by related parties.

\section{CONCLUSION}

The results of the study showed the lack of skills of MSMEs in trading business types in UniversitasGaluhCiamis in preparing financial reports. Evidenced by the tests conducted before providing training and applying a simple accounting format on their business, the average score obtained was 27.80. Meanwhile after accounting training was given to them, and after the 
application of a simple accounting format to their businesses, there was an increase in their skills in preparing financial statements using that format. Proven from the test after being given training and applying a simple accounting format, the average score obtained was 71.20.

This study has a weakness, namely, the analysis is carried out only on the ability of SMEs before and after accounting training and application of a simple accounting format, so that the impact of applying a simple accounting format to business development cannot be known. It is better for the next study, the analysis conducted is to change business conditions before and after accounting training is given, so that the contribution of accounting can be known to the development of MSMEs businesses.

\section{ACKNOWLEDGMENT}

Thank you to the Kemenrsitekdikti for the grant funding for this study. We are also grateful to Universitas Galuh Ciamis for the support it has provided, especially from the various facilities that have been provided to improve the skills and competence of its human resources.

\section{BIBLIOGRAPHY}

Akbar, D. S., \& Dedeh, D. (2017). Format Akuntansi Sederhana untuk Warung Tradisional. Jurnal Wawasan Dan Riset Akuntansi, 4(2), 121-130.

....., Faridah, E., Apip, M., \& Suhendi, R. M. (2019). Strategy of MSMEs Development in Facing The Industrial Era 4.0: in the Accounting Perspective. Jurnal Wawasan Dan Riset Akuntansi, 6(2), 110. https://doi.org/10.25157/jwr.v6i2.1946

Astuti, D. S. P. (2010). Perlunya Penerapan Sistem Akuntansi Pada Usaha Kecil Menengah. Jurnal Ekonomi Dan Kewirausahaan, 10(2), 152-163.

Azaria, V.M. (2013). Penerapan Akuntansi Pada UKM Unggulandi Kabupaten Kota Blitar dan kesesuaiannya dengan SAK ETAP. Univeritas Jember.

Badria, N., \& Diana, N. (2018). Persepsi Pelaku UMKM dan Sosialisasi SAK EMKM Terhadap Diberlakukannya Laporan Keuangan yang Berbasis SAK EMKM. Universitas Islam Malang, 55-66.

Ernawati, S., Asyikin, J., \& Sari, O. (2016). Penerapan Sistem Akuntansi Dasar Pada Usaha Kecil Menengah di Kota Banjarmasin. Jurnal Penelitian Ilmu Ekonomi WIGA, 6(2), 8191.

https://doi.org/journal.stiewidyagamalumajang.ac.id/index.php/JPWIGA/article/viewFile/7 9/133

Nurranto, H., Kurniadi, F., \& Gayatri, A. M. (2019). Tingkat Inovasi Sebagai Strategi pengembangan Produk Usaha Kecil Menengah di Desa Kebonharjo. Sosio E-Kons, 11(1), $1-15$.

Pawitan, G. (2012). Characteristics of Small Medium Manufacturing Industries In the Era of ACFTA : case study from West Java. Prcedia Economics and Finance, 4(Icsmed), 130139. https://doi.org/10.1016/S2212-5671(12)00328-0

Phijaisanit, E. (2017). AEC and the Changing Economic Landscape. In Internationalization and Managing Networks in the Asia Pacific. https://doi.org/10.1016/B978-0-08-1008133.00002-X

Salmiah, N., Nanda, S. T., \& Adino, I. (2018). Pemahaman Pelaku UMKM Terhadap SAK EMKM: Survey Pada UMKM Yang Terdaftar Di Dinas Koperasi Dan UKM Kota Pekanbaru. Akuntansi Dewantara, 2(2), 194-204. https://doi.org/http://dx.doi.org/10.29230/ad.v2i2.2767 


\section{sosio e-kons}

Volume 11, No. 3, Desember 2019, pp. 195-203

e-ISSN: 2502-5449

p-ISSN: 2085-2266

DOI : $10.30998 /$ sosioekons.v11i3.4385

Saragih, F., \& Surikayanti. (2015). Analisis Penerapan Akuntansi dan Kesesuaiannya dengan SAK ETAP pada UKM Medan Perjuangan. Seminar Nasional Ekonomi Manajemen Dan Akuntansi (SNEMA) Fakultas Ekonomi Universitas Negeri Padang, (c), 452-461.

Savitri, R. V., \& Saifudin, S. (2018). Pencatatan Akuntansi Pada Usaha Mikro Kecil dan Menengah (Studi Pada UMKM MR. Pelangi Semarang). Jurnal Manajemen Bisnis Dan Inovasi, 5(2), 117-125.

Wilujeng, S.M.R. (2013). Penerapan SAK ETAP Pada Usaha Mikro Kecil dan Menengah (Studi Kasus Distro Lollipop di Surabaya). Universitas Pembangunan Nasional "Veteran" Jawa Timur. 